\title{
The effect of exposure to aluminium on concentrations of essential metals in serum of foundry workers
}

\author{
H B Röllin, P Theodorou, T A Kilroe-Smith
}

\begin{abstract}
The concentrations of aluminium (A1) in serum and urine of 33 volunteers exposed to inhalation of $\mathrm{Al}_{2} \mathrm{O}_{3}$ dust at a concentration in the air of less than $1 \mathrm{mg} \mathrm{Al} / \mathrm{m}^{3}$ were measured. These were compared with results from 20 normal subjects not exposed. The concentrations of copper $(\mathrm{Cu})$, zinc $(\mathrm{Zn})$, and total iron $(\mathrm{Fe})$ in serum were also measured. The $\mathrm{Al}$ concentration in serum was significantly raised in the subjects exposed to dust, but Al concentrations in urine showed no significant difference from controls. This suggests a possible change in distribution of metals in the body tissues due to the presence of $\mathrm{Al}$, with incomplete excretion of $\mathrm{Al}$ in the urine. This redistribution was selective, as the serum concentrations of $\mathrm{Cu}$ were conclusively decreased whereas the serum concentrations of $\mathrm{Zn}$ were conclusively increased. The serum concentration of Fe did not change significantly.
\end{abstract}

Until recently aluminium ( $\mathrm{Al}$ ) was regarded as poorly absorbed and biologically inert in man, but there is now convincing evidence that it accumulates in patients with impaired renal function, mainly due to contamination of dialysis fluids with $\mathrm{Al}$, as well as by absorption of $\mathrm{Al}$ through the gut from $\mathrm{Al}$ containing phosphate binders used medicinally by these patients. In these subjects, $\mathrm{Al}$ exerts neurological toxicity (dementia) due to accumulation of $\mathrm{Al}$ in brain tissue. ${ }^{1}$ Increased concentrations of $\mathrm{Al}$ in the brain have also been found in patients suffering from Alzheimer's disease. ${ }^{2}$ Animal experiments have placed the neurotoxic effects of $\mathrm{Al}$ beyond doubt. ${ }^{3}$

Although occupational exposure to $\mathrm{Al}$ and its compounds is common, relatively few monitoring studies have been performed.

One case of dementia and pulmonary fibrosis in an Al powder production worker was described by

National Centre for Occupational Health, PO Box 4788, Johannesburg, 2000, South Africa

H B Röllin, P Theodorou, T A Kilroe-Smith
McLaughlin et al as long ago as $1962 .{ }^{4}$ Previous and recent studies on $\mathrm{Al}$ toxicity in industry have been confined to pulmonary function in $\mathrm{Al}$ smelters ${ }^{56}$ and epidemiological studies of mortality in $\mathrm{Al}$ reduction plant workers. ${ }^{78}$

One study by Longstreth et al, ${ }^{9}$ however, investigated three patients with a progressive neurological disorder, all of whom had worked for over 12 years in the same potroom of an Al smelting plant. The authors concluded that "it is theoretically possible that long term low level exposure to $\mathrm{Al}$ could lead to neurotoxicity." Studies investigating the actual concentrations of $\mathrm{Al}$ in biological fluids of occupationally exposed subjects are sparse, ${ }^{1011}$ due mainly to the analytical difficulties in analysing for $\mathrm{Al}$. This is partly because of its ubiquity so that contamination is difficult to avoid. Also, conflicting normal concentrations are reported.

We know that the route of absorption as well as the type of compound plays a paramount part in determining the toxicity of metals. The interaction of the toxic metal with essential trace elements is important in understanding its toxicity. The few published investigations of the interaction of $\mathrm{Al}$ with trace metals in man are concerned only with patients undergoing haemodialysis ${ }^{12}$ or dietary $\mathrm{Al}$ intake of healthy subjects. ${ }^{13}$ Little information exists about the interaction of $\mathrm{Al}$ with essential elements other than calcium and phosphate. ${ }^{14}$

In this communication we report the effect of exposure to $\mathrm{Al}$ on concentrations of essential metals in foundry workers. We measured concentrations of $\mathrm{Al}$ in serum and urine. Iron $(\mathrm{Fe})$, copper $(\mathrm{Cu})$, and zinc $(\mathrm{Zn})$ in the serum were also measured as well as lead $(\mathrm{Pb})$ and cadmium $(\mathrm{Cd})$ concentrations in whole blood. The $\mathrm{Al}$ exposed workers were compared with non-exposed subjects.

\section{Materials and methods}

Thirty three volunteers from the workers in two different foundries, who were exposed to aluminium dust and fumes, were investigated. They consisted of smelters, low and high pressure die casting operators, fettlers, and sand casters. All gave informed consent to the taking of their blood for this survey. A group of 20 normal, non-exposed subjects ${ }^{-}$was used for com- 
Table 1 Operating parameters for furnace atomic absorption spectrophotometry

\begin{tabular}{|c|c|c|c|c|c|c|c|c|c|}
\hline \multirow[b]{2}{*}{ Step } & \multicolumn{3}{|l|}{$P b$} & \multicolumn{3}{|l|}{$C d$} & \multicolumn{3}{|l|}{$C u$} \\
\hline & $\begin{array}{l}\text { Temp } \\
\left({ }^{\circ} \mathrm{C}\right)\end{array}$ & $\begin{array}{l}\text { Time } \\
(s)\end{array}$ & $\begin{array}{l}\text { Argon } \\
\text { (l/min) }\end{array}$ & $\begin{array}{l}\text { Temp } \\
\left({ }^{\circ} \mathrm{C}\right)\end{array}$ & $\begin{array}{l}\text { Time } \\
(s)\end{array}$ & $\begin{array}{l}\text { Argon } \\
(l / \min )\end{array}$ & $\begin{array}{l}\text { Temp } \\
\left({ }^{\circ} \mathrm{C}\right)\end{array}$ & $\begin{array}{l}\text { Time } \\
(s)\end{array}$ & $\begin{array}{l}\text { Argon } \\
(l / \text { min })\end{array}$ \\
\hline $\begin{array}{r}1 \\
2 \\
3 \\
4 \\
5 \\
6 \\
7 \\
8 \\
9 \\
10 \\
11\end{array}$ & $\begin{array}{c}75 \\
95 \\
140 \\
300 \\
450 \\
480 \\
480 \\
480 \\
2600 \dagger \\
2600 \dagger \\
2600\end{array}$ & $\begin{array}{r}2.0 \\
15.0 \\
10.0 \\
8.0 \\
7.0 \\
10.0 \\
5.0 \\
1.0 \\
1.1 \\
1.0 \\
2.0\end{array}$ & $\begin{array}{l}3.0 \\
3.0 \\
3.0 \\
3.0 \\
0.5^{\star} \\
0.5^{\star} \\
3 \cdot 0 \\
0.0 \\
0.0 \\
0.0 \\
3.0\end{array}$ & $\begin{array}{c}75 \\
95 \\
140 \\
180 \\
350 \\
450 \\
450 \\
1800 \dagger \\
1800 \dagger \\
1800\end{array}$ & $\begin{array}{r}2.0 \\
15.0 \\
10.0 \\
20.0 \\
20.0 \\
60.0 \\
1.0 \\
1.1 \\
2.0 \\
2.0\end{array}$ & $\begin{array}{l}3 \cdot 0 \\
3 \cdot 0 \\
3 \cdot 0 \\
0.5^{\star} \\
0.5^{\star} \\
3 \cdot 0 \\
0.0 \\
0.0 \\
0.0 \\
3 \cdot 0\end{array}$ & $\begin{array}{c}50 \\
80 \\
100 \\
120 \\
150 \\
600 \\
600 \\
2600 \dagger \\
2600 \dagger \\
2600\end{array}$ & $\begin{array}{r}10.0 \\
10.0 \\
5.0 \\
5.0 \\
10.0 \\
10.0 \\
5.0 \\
1.0 \\
1.5 \\
1.0\end{array}$ & $\begin{array}{l}3.0 \\
3.0 \\
3.0 \\
3.0 \\
3.0 \\
3.0 \\
0.5 \\
0.5 \\
0.5 \\
3.0\end{array}$ \\
\hline $\begin{array}{l}\text { Integration time (s) } \\
\text { Wavelength (nm) } \\
\text { Slit (nm) } \\
\text { Lamp current (mA) }\end{array}$ & & $\begin{array}{r}1 \cdot 0 \\
283 \cdot 3 \\
0.5 \\
5 \cdot 0\end{array}$ & & & $\begin{array}{r}1 \cdot 0 \\
228 \cdot 8 \\
0 \cdot 5 \\
4 \cdot 0\end{array}$ & & & $\begin{array}{r}0 \cdot 5 \\
324 \cdot 8 \\
0 \cdot 5 \\
4 \cdot 0\end{array}$ & \\
\hline
\end{tabular}

^Air replaces argon as carrier gas. $\nmid$ Read command: on. Mode: peak height. Background correction: on.

parison. The mean exposure time for the exposed workers ranged between one and 17 years with a median value of seven years.

Environmental $\mathrm{Al}$ at different work stations was measured with personal filters over a period of eight hours. Concentrations found were $0.17 \mathrm{mg} / \mathrm{m}^{3}$ for smelters, $0.027 \mathrm{mg} / \mathrm{m}^{3}$ for operators, and $0.58 \mathrm{mg} / \mathrm{m}^{3}$ for fettlers-that is, well below the $10 \mathrm{mg} / \mathrm{m}^{3}$ threshold limit value time weighted average proposed by the American Conference of Governmental Industrial Hygienists. ${ }^{15}$

Blood was collected in Venoject heparinised tubes (Terumo Corp., Tokyo, Japan) for $\mathrm{Pb}$ and $\mathrm{Cd}$ determinations. Blood for determination of $\mathrm{Cu}, \mathrm{Fe}$, $\mathrm{Zn}$, and $\mathrm{Al}$ concentrations in serum was collected into Sterilin tubes (Sterilab Services Catalogue No 144AS), which were found to be free of trace metals.

Syringes used were metal free B-D (sterile, disposable from Becton, Dickinson and Company, Rutherford, NY, USA). Urine was collected into acid washed polystyrene specimen bottles. Precautions were taken to avoid contamination during collection. Blood samples were stored at $4^{\circ} \mathrm{C}$ until analysed. The serum samples were analysed immediately for $\mathrm{Al}$ and then stored at $-20^{\circ} \mathrm{C}$ until analysed for the other metals. Specific gravity of urine was determined on the day of collection and the samples stored at $-20^{\circ} \mathrm{C}$ until analysed.

\section{INSTRUMENTATION}

A Varian model AA-975 atomic absorption spectrophotometer equipped with a GTA-95 furnace and autosampler as well as an HP-85 desktop computer was used. Deuterium background correction was applied in all cases. The purge gas was argon and in the case of blood for $\mathrm{Pb}$ and $\mathrm{Cd}$, air was introduced during the charring stage to help to oxidise the matrix.
PROCEDURE

In all cases micromethods by flameless atomic absorption spectrophotometry were used and standard graphs were prepared by the method of additions to overcome matrix interferences in biological specimens. Extreme care was taken to avoid and eliminate all possible contamination.

Blood for $\mathrm{Pb}$ and $\mathrm{Cd}$ determination was diluted $10-$ fold with $0 \cdot 1 \%$ Triton $X$ and $5 \mu$ laliquots were taken for the determinations. A tungsten coated tube was used as previously described. ${ }^{16}$ Table 1 gives the heating programmes for the graphite furnace.

The determination of $\mathrm{Cu}$ and total $\mathrm{Fe}$ concentrations in serum was modified from our methodology previously described for the Perkin-Elmer 603 $\mathrm{AAS}^{17} 18$ with adjustments of the heating parameters adapted to the Varian instrument (table 1). Table 1 also shows the parameters for determination of $\mathrm{Zn}$ concentrations in serum.

Determination of $\mathrm{Al}$ concentrations in serum was performed according to the method of Röllin et al $^{19}$ (10-fold dilution with $0.1 \mathrm{~N} \mathrm{HNO}_{3}$ ) on the day of collection to prevent contamination due to storage. ${ }^{20}$ Urine samples were diluted fivefold with $0 \cdot 1 \mathrm{~N}$ $\mathrm{HNO}_{3}$ and $\mathrm{Al}$ was determined by the method of addition. Specific gravity of urine was measured using a refractometer.

\section{STATISTICAL METHODS}

Student's $t$ test was used. Differencés were considered statistically significant when $\mathrm{p}<0.05$. Criteria were according to Miller. ${ }^{21}$

\section{Results}

Table 2 shows the statistical differences between normal and industrially exposed subjects.

Because $\mathrm{Zn}$ concentrations were significantly raised in exposed subjects, personal filters were also 


\begin{tabular}{|c|c|c|c|c|c|c|c|c|}
\hline \multicolumn{3}{|l|}{$F e$} & \multicolumn{3}{|l|}{$Z n$} & \multicolumn{3}{|l|}{$A l$} \\
\hline $\begin{array}{l}\text { Temp } \\
\left({ }^{\circ} \mathrm{C}\right)\end{array}$ & $\underset{(s)}{\text { Time }}$ & $\begin{array}{l}\text { Argon } \\
(l / \text { min })\end{array}$ & $\begin{array}{l}\text { Temp } \\
\left({ }^{\circ} \mathrm{C}\right)\end{array}$ & $\begin{array}{l}\text { Time } \\
(s)\end{array}$ & $\begin{array}{l}\text { Argon } \\
(l / \text { min })\end{array}$ & $\begin{array}{l}\text { Temp } \\
\left({ }^{\circ} \mathrm{C}\right)\end{array}$ & Time & $\begin{array}{l}\text { Argon } \\
\text { (l/min) }\end{array}$ \\
\hline \multirow[t]{2}{*}{$\begin{array}{c}50 \\
80 \\
100 \\
120 \\
150 \\
600 \\
600 \\
2400 \dagger \\
240{ }^{\dagger} \\
2400\end{array}$} & $\begin{array}{r}10.0 \\
10.0 \\
5.0 \\
5.0 \\
10.0 \\
10.0 \\
5.0 \\
1.1 \\
1.0 \\
2.0\end{array}$ & $\begin{array}{l}3.0 \\
3.0 \\
3.0 \\
3.0 \\
3.0 \\
3.0 \\
3.0 \\
0.5 \\
0.5 \\
3.0\end{array}$ & $\begin{array}{c}75 \\
90 \\
120 \\
150 \\
400 \\
400 \\
400 \\
1900 \dagger \\
1900 \dagger \\
1900\end{array}$ & $\begin{array}{r}5.0 \\
60.0 \\
10.0 \\
5.0 \\
10.0 \\
10.0 \\
5.0 \\
1.0 \\
2.0 \\
1.0\end{array}$ & $\begin{array}{l}3 \cdot 0 \\
3 \cdot 0 \\
3 \cdot 0 \\
3 \cdot 0 \\
3 \cdot 0 \\
3 \cdot 0 \\
0 \cdot 7 \\
0 \cdot 7 \\
0 \cdot 7 \\
3 \cdot 0\end{array}$ & $\begin{array}{c}50 \\
80 \\
100 \\
120 \\
150 \\
1000 \\
1000 \\
2500 \dagger \\
2500 \dagger \\
2500\end{array}$ & $\begin{array}{r}10.0 \\
10.0 \\
5.0 \\
5.0 \\
10.0 \\
10.0 \\
5.0 \\
1.0 \\
1.5 \\
1.0\end{array}$ & $\begin{array}{l}3.0 \\
3.0 \\
3.0 \\
3.0 \\
3.0 \\
3.0 \\
0.0 \\
0.0 \\
0.0 \\
3.0\end{array}$ \\
\hline & $\begin{array}{r}1.0 \\
248 \cdot 3 \\
0.5 \\
5.0\end{array}$ & & & $\begin{array}{r}1.0 \\
213.9 \\
1.0 \\
5.0\end{array}$ & & & $\begin{array}{r}1.0 \\
309.3 \\
0.5 \\
5.0\end{array}$ & \\
\hline
\end{tabular}

analysed for $\mathrm{Zn}$ content and contained no $\mathrm{Zn}$. Serum $\mathrm{Al}$ concentrations for control subjects ranged between 0.25 and $2.26 \mu \mathrm{g} / \mathrm{dl}$ with mean 1.13 (SD 0.55) $\mu \mathrm{g} / \mathrm{dl}$. Urinary $\mathrm{Al}$ concentrations ranged between $7 \cdot 86-17 \cdot 19 \mu \mathrm{g} / \mathrm{l}$, mean 12.90 (SD 3.35) $\mu \mathrm{g} / \mathrm{l}$. Mean concentrations for $\mathrm{Cu}$ were $145 \mu \mathrm{g} / \mathrm{dl}$, for $\mathrm{Zn}$ $89 \mu \mathrm{g} / \mathrm{dl}$, and for total serum $\mathrm{Fe} 177 \mu \mathrm{g} / \mathrm{dl}$, which are within accepted normal values.

Values reported for $\mathrm{Al}$ in serum and urine vary widely between different authors. ${ }^{22}$ Dietary, geographical, methodological, or even seasonal differences can influence the result. ${ }^{23}$ This makes it difficult to compare our results with other published values.

The mean concentrations for $\mathrm{Pb}$ and $\mathrm{Cd}$ in blood of exposed subjects were $12.63 \mu \mathrm{g} / \mathrm{dl}$ and $0.126 \mu \mathrm{g} / \mathrm{dl}$ respectively. These concentrations of $\mathrm{Pb}$ and $\mathrm{Cd}$ in blood were within the normal reported ranges. ${ }^{24} 25$ This fact excludes the possibility of $\mathrm{Pb}$ or $\mathrm{Cd}$ having an effect on the concentrations of the measured essential metals, which could lead to false conclusions about the effects of Al. A significant increase in the concentrations of $\mathrm{Al}$ in serum was found in the exposed subjects compared with normal values $(p<$ $0.05)$ but no significant difference was found $(\mathrm{p}>$ $0 \cdot 1)$ for urine.

The concentrations of serum $\mathrm{Cu}$ were lower in exposed subjects $(\mathrm{p} \ll 0.001)$ and the concentration of serum $\mathrm{Zn}$ higher $(\mathrm{p} \ll 0.001)$ compared with normal values. No significant difference in concentration of total serum Fe was found between normal and exposed groups. We did not find statistical differences in concentrations of any of those metals between different sites of exposure.

\section{Discussion}

It is evident from our study that even low $\mathrm{Al}$ exposure has an effect on concentrations of two major essential elements-namely, $\mathrm{Cu}$ and $\mathrm{Zn}$. The $\mathrm{Al}$ concentrations measured in the air of these factories were well below threshold limit values and the increase in concentrations of $\mathrm{Al}$ in serum were only just significant $(p<0.05)$. Also, the urinary excretion of $\mathrm{Al}$ was not increased at these concentrations suggesting that it is not excreted readily and probably accumulates in other organs first.

Kavalchik et al ${ }^{26}$ suggest that plasma may have a limited ability for $\mathrm{Al}$ binding. Excess of $\mathrm{Al}$ may then be translocated to other tissue stores making it unavailable for excretion.

To be able to explain why minute amounts of $\mathrm{Al}$ can exert unquestionable neurotoxic effects, the mode of its absorption and the mechanism by which it is transported within the physiological environment must be investigated. Birchall et al ${ }^{27}$ suggest that the strong binding of $\mathrm{Al}$ by adjacent phosphate groups on inositol and slow ligand exchange charac-

Table 2 Comparison of concentrations of metals in normal and industrially exposed subjects

\begin{tabular}{|c|c|c|c|}
\hline Sample & Normal subjects $(n=20)$ & Exposed subjects $(n=33)$ & p Value \\
\hline $\begin{array}{l}\text { Serum Al }(\mu \mathrm{g} / \mathrm{dl}) \\
\text { Urine } \mathrm{Al}(\mu \mathrm{g} / \mathrm{l}) \\
\text { Serum } \mathrm{Cu}(\mu \mathrm{g} / \mathrm{dl}) \\
\text { Serum } \mathrm{Zn}(\mu \mathrm{g} / \mathrm{dl}) \\
\text { Serum } \mathrm{Fe}(\mu \mathrm{g} / \mathrm{dl})\end{array}$ & $\begin{array}{rr}1 \cdot 13 & (0.55) \\
12.90 & (3.35) \\
144.90 & (38.47) \\
88.68 & (15 \cdot 11) \\
177.20 & (48.40)\end{array}$ & $\begin{array}{rr}1.60 & (0.88) \\
18.93 & (15.38) \\
99.27 & (15.37) \\
127.63 & (29.14) \\
147.41 & (51.98)\end{array}$ & $\begin{array}{l}<0.05 \\
>0.1 \\
\ll 0.001 \\
\ll 0.001 \\
>0.1\end{array}$ \\
\hline
\end{tabular}

Results are expressed as mean (SD).

$\star$ Two tailed Student's $t$ test. 
teristics of $\mathrm{Al}$ would be expected to have a profound effect on the function of the phosphatidylinositol derived second messenger system.

The findings by Altman et $a l^{28}$ show that low $\mathrm{Al}$ concentrations inhibit haemoglobin synthesis. Interaction of a toxic metal with essential elements plays a major part in its toxicity. If the molecular site on an enzyme normally occupied by the essential metal is usurped by a toxic metal, toxic effects will be seen.

We found that $\mathrm{Al}$ influences serum concentrations of $\mathrm{Cu}$ and $\mathrm{Zn}$ in workers exposed to less than $1 \mathrm{mg} / \mathrm{m}^{3}$ aluminium dust. It will be of interest to find out what changes occur in other soft tissues and bone at similar levels of exposure. This requires a controlled animal experiment at low concentrations of $\mathrm{Al}$ exposure and this is in progress.

We thank Mr R Cronje from the Industrial Hygiene Section at our centre for his assistance in collecting the dust samples used for determining the environmental exposure, and to sister Rosalie Lowe from the Epidemiology Section of the $\mathrm{NCOH}$ for collecting the blood samples.

Requests for reprints to: Helen B Röllin.

1 Alfrey AC, Legendre GR, Kaehny WD. The dialysis encephalopathy syndrome. Possible aluminum intoxication. N Engl J Med 1976;274:184-8.

2 Crapper-McLachlan DR, Lukiw WJ, Kruck TPA. New evidence for an active role of aluminum in Alzheimer's Disease. Canadian Journal of Neurological Science 1989;16: 490-7.

3 Wisniewski HM, Sturman JA, Shek JW. Aluminium chloride induced neurofibrillary changes in the developing rabbit: a chronic animal model. American Journal of Neurology 1980; 8:479-90.

4 McLaughlin AIG, Kazantis G, King E, Teare D, Porter RJ, Owen R. Pulmonary fibrosis and encephalopathy associated with the inhalation of aluminium dust. $\mathrm{Br} J$ Ind Med 1962;19:253-63.

5 Field GB. Pulmonary function in aluminium smelters. Thorax 1984;39:743-51.

6 Larsson K, Eklund A, Arns R, et al. Lung function and bronchial reactivity in aluminum potroom workers. Scand J Work Environ Health 1989;15:296-301.

7 Gibbs GW. Mortality of aluminum reduction plant workers, 1950 through 1977. J Occup Med 1985;27:761-70.

8 Mur JM, Moulin JJ, Meyer-Bisch C, Massin N, Coulon JP, Loulergue J. Mortality of aluminum reduction plant workers in France. Int J Epidemiol 1987;16:257-64.
9 Longstreth WT Jr, Rosenstock L, Heyer NJ. Potroom palsy? Neurological disorders in three aluminum smelter workers. Archives of Internal Medicine 1985;145:1972-5.

10 Sjörgen B, Lundberg I, Lidums V. Aluminium in the blood and urine of industrially exposed workers. $\mathrm{Br} J$ Ind Med 1983; 40:301-4.

11 Mussi I, Calzaferri G, Buratti M, Alessio L. Behaviour of plasma and urinary aluminium levels in occupationally exposed subjects. Int Arch Occup Environ Health 1984;54:155-61.

12 Navarro JA, Parra OE, Garcia R, et al. Trace metal levels during hemodialysis in patients with chronic renal failure. Trace Elements in Medicine 1989;6:70-4.

13 Greger JL, Baier M. Effect of dietary aluminum on mineral metabolism of adult males. Am J Clin Nutr 1983;38:411-9.

14 Cam JM, Luck VA, Eastwood JB, deWardener HE. The effect of aluminium hydroxide orally on calcium, phosphorus and aluminium metabolism in normal subjects. Clinical Science and Molecular Medicine 1976;51:407-14.

15 American Conference of Governmental Industrial Hygienists. $T L V$ 's-Threshold limit values for chemical substances in the work environment for 1989-1990. Cincinnati: ACGIH, 1990.

16 Baily P, Norval E, Kilroe-Smith TA, Skikne MI, Röllin HB. The application of metal-coated graphite-tubes to the determination of trace metals in biological materials. The determination of lead in blood using a tungsten-coated graphitetube. Microchemical Journal 1979;24:107-16.

17 Baily P, Kilroe-Smith TA, Röllin HB. Effect of sample preparation and matrix on copper determinations in biological specimens by flameless atomic absorption spectroscopy. Laboratory Practice 1980;29:141-3.

18 Baily P, Röllin HB, Kilroe-Smith TA. Comparison of a graphite tube micromethod for the determination of serum iron and total iron-binding capacity with spectrophotometric techniques. Microchemical Journal 1981;26:250-61.

19 Röllin HB, Theodorou P, Kilroe-Smith TA. Determination of aluminium in small samples of serum and biopsy samples of bone and soft tissues. Microchemical Journal 1987;35:373-8.

20 Kilroe-Smith TA, Röllin HB. Some observations of the effect of ashing temperature on the determination of aluminum in serum by furnace atomic absorption spectroscopy. Microchemical Journal 1990 (in press).

21 Miller DA. Significant and highly significant. Nature 1966;210: 1190.

22 Cedergren A, Frech W. Determination of aluminium in biological materials by graphite furnace atomic absorption spectrometry. Pure and Applied Chemistry 1987;59:221-8.

23 Nordal KP, Dahl E, Thomassen Y, Brodwell EK, Halse J. Seasonal variations in serum aluminum concentrations. Pharmacol J Toxicol 1988;62:80-3.

24 Pocock SJ, Delves HT, Ashby D, Shaper AG, Clayton BE. Blood cadmium concentrations in the general population of British middle-aged men. Hum Toxicol 1988;7:95-103.

25 Clausen J, Rastogi SC. Heavy metal pollution among autoworkers. Br J Ind Med 1977;34:208-15.

26 Kavalchik MT, Kaehny WD, Hegg AP, Jackson JT, Alfrey AC. Aluminium kinetics during hemodialysis. J Lab Clin Med 1978;92:712-20.

27 Birchall JD, Chappell JS. Aluminium, chemical physiology and Alzheimer's disease. Lancet 1988;ii:1008-10.

28 Altman P, Marsh F, Plowman D, Cunningham J. Aluminium chelation therapy in dialysis patients: Evidence for inhibition of haemoglobin synthesis by low levels of aluminium. Lancet 1988;i:1012-5.

Accepted 1 October 1990 